\title{
THE EFFECT OF FOREIGN DIRECT INVESTMENT ON ECONOMIC GROWTH IN KOSOVO
}

\author{
Isuf Qabrati \\ MSc of Accounting and Auditing, \\ Faculty of Economics, \\ University of Prizren, \\ Prizren, Kosovo
}

\begin{abstract}
:
Foreign direct investment plays a very important role in the economic development of countries, especially in countries in transition. Foreign direct investment is defined as any investment where the investor invests in a foreign country the factors of production including labor, financial capital, technology and professional management knowledge. FDI can ensure financial stability, promote economic development and improve social welfare. The purpose of this paper is to investigate the impact of FDI on Kosovo's economic growth, for the years 2007-2017. In particular, the paper aims to measure the effect that FDI has had on GDP over the years, examining the impact of FDI by economic activities on economic growth, expressed in GDP. Two basic variables were used: the independent variable (FDI) and the dependent variable (GDP). To measure the effect of the independent variable on the dependent variable, the data realized for these two variables were collected by the relevant public institutions. From the derived data, the results of the regression analysis show that FDI has a significant effect on economic growth. The change in economic growth depends almost entirely on the change in FDI by sectors of economic activity.
\end{abstract}

JEL: E20, E22

Keywords: foreign direct investment, economic growth, gross domestic product

\section{Introduction}

Foreign direct investment is a very important segment of a country's economic activity, due to the effects that the latter bring. Foreign direct investment (FDI) is a source of capital and a driver of economic growth in developing countries, especially in the context of the move towards privatization and globalization. Foreign direct investment is already

\footnotetext{
${ }^{i}$ Correspondence: email isufqabrati@gmail.com
} 
an important part of national development strategies for many different countries, especially for developing and transition countries. Driven by technological change, global competition and market liberalization, foreign direct investment plays a key role in the process of global economic integration. They create effects in both host and investing countries. Policy makers and academics often argue that developing countries should attract foreign direct investment (FDI) as a means to generate higher economic growth by providing local firms with a direct source of capital funding and valuable externalities of productivity (Alfaro \& Matthew, 2012).

The purpose of this paper is to investigate the impact of FDI on Kosovo's economic growth, for the years 2007-2017. In particular, the paper aims to measure the effect that FDI has had on GDP over the years, examining the impact of FDI by economic activities on economic growth, expressed in GDP.

\section{Literature Review}

There are a number of studies in the field of FDI and economic growth. It is now generally accepted that FDI plays a crucial role in the industrial development of developed and developing countries and can help boost economic growth through, for example, total factor productivity growth (Bartels \& Crombrugghe, 2009).

Empirical results reveal that the size of the market, namely the gross domestic product of the Nigerian economy attracts foreign direct investment, as the increase in production causes the inflow of FDI to increase by approximately 2.35\%. Maku, 2015). Foreign direct investment (FDI) has contributed to impressive economic growth in a number of developing countries. In general, FDI not only increases the supply of capital but given the appropriate policies of the host country, it can also facilitate technology transfer. Technology transfer contributes to the formation of human capital which can further improve economic growth prospects. In other words, FDI can facilitate economic growth through direct and indirect channels (Anwar \& Nguyen, 2010). Omri (2014) shows that the effect of the stock of FDI on economic growth in MENA countries is positive and statistically significant. Bengoa and Sanchez-Robles (2003) using panel data for Latin America, examined the relationship between FDI, economic freedom and economic growth. Comparing fixed and random effects estimates, they conclude that FDI has a significant positive effect on host country economic growth.

Jyun-Yi and Chih-Chiang (2008) in their study they analyzed whether the FDI promote the economic growth by using threshold regression analysis. According to their analysis it shows that FDI alone play uncertain role in contributing to economic growth based on a sample of 62 countries during the period observed from 1975 to 2000 and find that initially GDP and human capital are important factor in explaining FDI. Further, FDI is found to have a positive and significant impact on growth when host countries have a better level of initial GDP and human capital.

Mehic and Babic-Hodovic (2013) investigated the impact of foreign direct investment (FDI) on economic growth in the transition countries of southeast Europe. 
The empirical analysis embraces seven southeast European countries in the period 19982007. The authors use Prais-Winsten regression with panel-corrected standard errors for the preferred estimation model. The main research result is the positive and statistically significant effect of FDI on economic growth. The impact of FDI is statistically significant and robust when including data on domestic investments.

According to Çakërri (2019), foreign investments are expected to have a significant impact on the economic growth and development of host countries. In general, in theory, FDI is expected to boost economic growth in host countries by creating employment opportunities, increasing domestic investment, and facilitating technology transfer. Hence there are numerous authors who have addressed this connection, both theoretically and empirically.

Also to have a clear picture of the problem are reviewed the empirical scientific research of the authors done so far dealing with foreign direct investment and economic growth (Javorick, 2004; Alvaro et al., 2006; Mottaleb, 2007; Falki, 2009; Denisia, 2010; Louzi \& Abadi, 2011; Adefabi, 2011; Dritsaki, C. \& Dritsaki, M., 2012; Dritsakis \& Stamatiou, 2014; Kilic, Bayar \& Arica, 2014; Kukaj \& Ahmeti, 2016; Siddique et al., 2017). The results of the various studies reviewed of has proven a significant relationship and confirm existence of co-integration between of foreign direct investments and economic growth.

\subsection{Foreign Direct Investments (FDI) flows and Gross Domestic Product (GDP) in Kosovo}

Below are presented the data of FDI and GDP for the reference period 2007-2017, as well as FDI by economic activity, which are further used for research analyses.

Table 1: FDI and GDP for the Years 2007-2017

\begin{tabular}{|c|c|c|}
\hline Year & FDI & GDP \\
\hline 2007 & 440,7 & $4,210,0$ \\
\hline 2008 & 369,9 & $3,882,7$ \\
\hline 2009 & 287,4 & $4,069,6$ \\
\hline 2010 & 368,5 & $4,402,0$ \\
\hline 2011 & 384,4 & $4,814,5$ \\
\hline 2012 & 229,1 & $5,058,8$ \\
\hline 2013 & 280,2 & $5,326,7$ \\
\hline 2014 & 151,2 & $5,567,5$ \\
\hline 2015 & 308,8 & $5,807,0$ \\
\hline 2016 & 220,0 & $6,070,1$ \\
\hline 2017 & 287,8 & $6,282,2$ \\
\hline
\end{tabular}

Source: Data are derived from CBK and KSA.

Foreign direct investments in Kosovo have started since 2000, while the most voluminous investments were made in 2007-2008. Major investments of the years 2007-2008 are identified as investments in the second mobile telephony in Kosovo. The decline in foreign direct investment was observed from late 2008 and early 2009 due to the economic 
crisis where foreign investment declined sharply. Meanwhile, in 2010-2011, I started to increase investments, although at a very slow pace. Table 2 below shows FDI by economic activity.

Table 2: FDI in Kosovo by Economic Activity

\begin{tabular}{|c|c|c|c|c|c|c|c|c|c|c|c|}
\hline $\begin{array}{l}\text { Year } \\
\text { Description }\end{array}$ & ڤ્ণે & ๕્సે & ஓ्ন & 옹 & न्ञ & 구ำ & 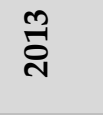 & ন্ণ & 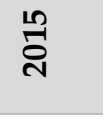 & ֻัं & 윰 \\
\hline Total & 440 & 369.9 & 287.4 & 368.5 & 384.4 & 229.1 & 280.2 & 151.2 & 308.8 & 220.0 & 287.8 \\
\hline Agriculture & 7.9 & 8.5 & 13.1 & 0.9 & 0.6 & 0.3 & 0.4 & 0.2 & 1.0 & 1.2 & -1.3 \\
\hline Mines & 41.5 & 17.4 & 7.0 & 17.7 & -5.2 & -25.0 & -14.1 & 4.2 & -36.9 & -19.1 & 4.59 \\
\hline Industry & 74.8 & 53.7 & 57.6 & 101.1 & 46.9 & 27.4 & 11.5 & -34.0 & 20.7 & 4.6 & -32.7 \\
\hline Energy & 2.5 & 16.7 & 8.7 & $\ldots$ & 0.3 & 2.2 & 48.8 & 13.4 & 11.9 & 3.4 & -1.0 \\
\hline Building & 5.2 & 13.5 & 35.5 & 54.2 & 133.1 & 31.1 & 17.3 & -19.9 & 46.3 & 28.2 & 4.7 \\
\hline $\begin{array}{l}\text { Commercial } \\
\text { services }\end{array}$ & 12.7 & 10.1 & 16.2 & 6.8 & 11.6 & 9.3 & 14.6 & 8.4 & 12.0 & 14.5 & 89.8 \\
\hline $\begin{array}{l}\text { Hotels and } \\
\text { Restaurants }\end{array}$ & 12.7 & 2.1 & 2.4 & $\ldots$ & 0.2 & 0.5 & 0.8 & 0.4 & 0.0 & 0.7 & 0.8 \\
\hline $\begin{array}{l}\text { Transport and } \\
\text { communication }\end{array}$ & 129.2 & 51.0 & 21.9 & -15.9 & 29.0 & 32.4 & 51.0 & -9.1 & -6.1 & -9.1 & -6.6 \\
\hline $\begin{array}{l}\text { Financial } \\
\text { services }\end{array}$ & 102.0 & 109.6 & 75.3 & 39.4 & 33.0 & 22.4 & 4.4 & 41.9 & 64.3 & 19.0 & 55.3 \\
\hline $\begin{array}{l}\text { Real estate, } \\
\text { renting and } \\
\text { other business } \\
\text { activities }\end{array}$ & 30.9 & 62.2 & 43.9 & 75.5 & 60.5 & 115.7 & 136.1 & 142.1 & 189.6 & 167.6 & 187.3 \\
\hline Other services & 4.5 & 2.1 & 2.7 & 1.3 & 11.3 & 1.8 & 3.3 & 2.2 & 4.5 & 9.4 & 4.9 \\
\hline $\begin{array}{l}\text { Activities not } \\
\text { classified } \\
\text { elsewhere }\end{array}$ & 16.9 & 23.0 & 11.3 & 87.6 & 63.2 & 11.0 & 6.2 & 1.4 & 1.4 & -0.6 & 1.5 \\
\hline
\end{tabular}

Source: $(C B K, 2019) *$ (education, health and social work, social and personal services)

\section{Research Methodology}

\subsection{Research Variables}

The study consists of the following variables:

Independent variable: Foreign direct investment (FDI),

Dependent variable: Economic growth (Gross domestic product - GDP).

\subsection{Procedures}

To measure the effect of the independent variable on the dependent variable, data were collected on these two variables by the Central Bank of Kosovo (CBK) and the Kosovo Agency of Statistics (KAS). Data collection was performed using primary and secondary data. Adequate literature review has been done in advance regarding the effect that FDI has on GDP. Data were analyzed using SPSS program. 


\subsection{Research Hypotheses}

The causal hypotheses which will be verified during this study are, as follows:

H1: There is a significant impact of FDI on economic growth.

H2: There is a significant impact of FDI on economic growth by sectors of economic activity.

\section{Data Analysis and Results}

The processed data were analyzed using SPSS program. Hypothesis testing was done on the multiple linear regression model. To test statistically the significance of the parameters separately the $t$ test is used and to test the model whether it is important as a whole, the F test is used.

\subsection{Descriptive Statistics Data}

Table 3 provides a summary of descriptive research statistics. The minimum, maximum, average and standard deviation values according to the data set shown are presented.

The average for the FDI indicator is 3025.45 , for the GDP indicator is 50446.455.

In terms of economic activity, the average for agriculture is 31 , for mining is 175.60 , for industry is 442.56 , for energy is 119.78 , for construction is 409.10 , for commercial services is 114.55 , for hotels and restaurants is 22.89 , for transp. and commune. is 524.17 , for financial services. 515.09, for real estate, rent and business activities is 1101.27, for other services is 43.64 and for other activities is 215.40 . As for the standard deviation, since the values are expressed in mil. $(€)$, as such, we can say that all are acceptable.

Table 3: Descriptive Statistics

\begin{tabular}{|l|c|c|c|c|}
\hline & Min & Max & Mean & St. Dev \\
\hline FDI & 1512 & 4407 & 3025.45 & 841.262 \\
\hline GDP & 38827.0 & 62822.0 & 50446.455 & 8355.1414 \\
\hline Agriculture & 2 & 131 & 31.00 & 45.217 \\
\hline Mines & 42 & 415 & 175.60 & 146.899 \\
\hline Industry & 46 & 1011 & 442.56 & 314.702 \\
\hline Energy & 2 & 488 & 119.78 & 149.527 \\
\hline Building & 52 & 1331 & 409.10 & 358.857 \\
\hline Commercial services & 68 & 162 & 114.55 & 28.943 \\
\hline Hotels and Restaurants & 2 & 127 & 22.89 & 39.769 \\
\hline Transport and Communication & 219 & 1292 & 524.17 & 394.461 \\
\hline Financial services & 44 & 1096 & 515.09 & 337.237 \\
\hline Real Est. Rent and Bus. Activities & 309 & 1896 & 1101.27 & 582.447 \\
\hline Other services & 13 & 113 & 43.64 & 32.166 \\
\hline Other activities & 14 & 876 & 215.40 & 298.491 \\
\hline
\end{tabular}




\subsection{Correlation Analysis}

Table 4: Correlation Analysis Results

\begin{tabular}{|c|c|c|c|c|c|c|c|c|c|c|}
\hline & 1 & 2 & 3 & 4 & 5 & 6 & 7 & 8 & 9 & 10 \\
\hline Year & 1 & & & & & & & & & \\
\hline FDI & $-.659^{*}$ & 1 & & & & & & & & \\
\hline GDP & $.980^{* *}$ & $-.604^{*}$ & 1 & & & & & & & \\
\hline Agriculture & $-.711^{*}$ & .373 & $-.734^{*}$ & 1 & & & & & & \\
\hline Mines & -.720 & .845 & -.424 & .146 & 1 & & & & & \\
\hline Industry & $-.787^{*}$ & $.730^{*}$ & $-.791^{*}$ & .382 & .242 & 1 & & & & \\
\hline Energy & .146 & -.140 & .111 & -.144 & -.677 & -.372 & 1 & & & \\
\hline Building & .132 & .174 & .094 & -.360 & -.626 & .093 & -.339 & 1 & & \\
\hline Commercial services & -.034 & .017 & -.016 & .463 & .092 & -.508 & .226 & -.191 & 1 & \\
\hline Hotels and Restaurants & -.620 & .643 & -.472 & .495 & $.960^{*}$ & 683 & -.216 & -.414 & .184 & 1 \\
\hline Transport and Communication & -.567 & .677 & -.242 & .162 & $.999^{*}$ & .504 & -.059 & -.479 & -.023 & $.937^{* *}$ \\
\hline Financial services & -.583 & .549 & -.562 & $.739^{* *}$ & .559 & .497 & -.279 & -.306 & -.004 & .627 \\
\hline Real Est. Rent and Bus. Activities & $.957^{* *}$ & $-.627^{*}$ & $.944^{* *}$ & $-.682^{*}$ & -.638 & $-.769^{*}$ & .257 & -.062 & -.078 & -.568 \\
\hline
\end{tabular}

Table 4 presents the results of the correlation, which was used to test the relationship between the variables and measure this relationship. According to the correlation results, a negative correlation was found between FDIs over the years $(r=-.659, p<.05)$, GDP has a strong positive correlation over the years $(\mathrm{r}=.980, \mathrm{p}<.01)$, while a negative correlation between FDI and GDP $(r=-.604, p<.05)$. From this we can say that, with the increase of years (between the years 2007-2017), FDI has decreased, while GDP has increased during these years. In terms of economic activities, real estate, renting and business activities have a stronger connection $(\mathrm{r}=.957, \mathrm{p}<.01)$, which shows that with the growth (over the years) these activities have also increased. There is also a positive correlation between them and GDP. Other correlative effects are due to the very nature of the interconnected nature of the sectors of economic activity.

\subsection{Regression Analysis}

The following is a test of the research hypotheses.

\section{Model 1:}

H1: There is a significant impact of FDI on economic growth.

The summary table of model 1 (Table 5) is an important table. Using the Enter method, in this table are given the values $R$ and $R$ Square which represent the degree of explanation of the variable dependent on the independent variables. The value that is interpreted is R Square which shows that the change in economic growth depends $36.5 \%$ on the change in the independent variables. So, foreign direct investment affects $36.5 \%$ of economic growth. 


\begin{tabular}{|c|c|c|c|c|c|c|c|c|c|c|}
\hline \multicolumn{7}{|c|}{ Table 5: Model Summary 1b } \\
\hline Model & $\mathbf{R}$ & $\begin{array}{c}\mathbf{R} \\
\text { Square }\end{array}$ & $\begin{array}{c}\text { Adjusted } \\
\text { R Square }\end{array}$ & $\begin{array}{c}\text { Std. Error } \\
\text { of the } \\
\text { Estimate }\end{array}$ & $\begin{array}{c}\text { R } \\
\text { Square } \\
\text { Change }\end{array}$ & $\begin{array}{c}\text { F } \\
\text { Change }\end{array}$ & df1 & df2 & $\begin{array}{c}\text { Sig. F } \\
\text { Change }\end{array}$ & $\begin{array}{c}\text { Durbin- } \\
\text { Watson }\end{array}$ \\
\hline 1 & $.604^{a}$ & .365 & .294 & 7018.2974 & .365 & 5.172 & 1 & 9 & .049 & 1.023 \\
\hline a. Predictors: (Constant), FDI & & & & & & \\
\hline
\end{tabular}

To see if this impact is significant, the Anova table is used, as shown below. Here, the ANOVA table gives the level of reliability for the regression model. Value Sig. is .049, and indicates that the model is significant at its level.

Table 6: ANOVA Table for the Regression Model 1a

\begin{tabular}{|l|l|c|c|c|c|c|}
\hline Model & Sum of Squares & df & Mean Square & F & Sig. \\
\hline 1 & Regression & 254775385.110 & 1 & 254775385.110 & $\mathbf{5 . 1 7 2}$ & $\mathbf{. 0 4 9}$ \\
\hline Residual & 443308489.617 & 9 & 49256498.846 & & \\
\hline \multicolumn{2}{|l|}{ Total } & 698083874.727 & 10 & & \\
\hline $\begin{array}{l}\text { a. Dependent Variable: GDP } \\
\text { b. Predictors: (Constant), FDI }\end{array}$
\end{tabular}

And at the bottom is the table of coefficients, which is presented below.

Table 7: Regression Coefficients of Model 1a

\begin{tabular}{|c|c|c|c|c|c|c|}
\hline \multirow{2}{*}{ Model } & \multicolumn{2}{|c|}{ Unstandardized Coefficients } & Standardized Coefficients & t & Sig. \\
\cline { 2 - 7 } & B & Std. Error & Beta & & \\
\hline $\mathbf{1}$ & (Constant) & 68599.024 & 8257.370 & & 8.308 & .000 \\
\cline { 2 - 7 } & FDI & -6.000 & 2.638 & -.604 & -2.274 & .049 \\
\hline
\end{tabular}

To summarize, the model forecast result is as follows:

$$
\mathrm{GDP}=68599.024-6 \mathrm{X}
$$

The constant value is 68599.024 which means that even if FDI will be zero, GDP will be 68599.024. With the increase of one unit in FDI, the GDP will decrease by 6,000 units. As a result we conclude that there is a significant impact of FDI on economic growth and $\mathbf{H} 1$ hypothesis is successfully accepted.

\section{Model 2:}

H2: There is a significant impact of FDI on economic growth by sectors of economic activity.

The following table presents the summary table of model 2. Using the Forward Selection method, which puts the variables in order according to the correlation power with the dependent variable, where the impact of each variable entered in the model is 
measured and variables that do not significantly affect are derived from the model. In this table again are given the values $R$ and $R$ Square which represent the degree of explanation of the variable dependent on the independent variables.

Table 8: Model Summary 2c

\begin{tabular}{|c|c|c|c|c|c|c|c|c|c|c|}
\hline \multirow[t]{2}{*}{ Model } & \multirow[t]{2}{*}{$\mathbf{R}$} & \multirow{2}{*}{$\begin{array}{c}\mathbf{R} \\
\text { Square }\end{array}$} & \multirow{2}{*}{$\begin{array}{l}\text { Adjusted } \\
\text { R Square }\end{array}$} & \multirow{2}{*}{$\begin{array}{l}\text { Std. Error } \\
\text { of the } \\
\text { Estimate }\end{array}$} & \multicolumn{5}{|c|}{ Change Statistics } & \multirow{2}{*}{$\begin{array}{l}\text { Durbin- } \\
\text { Watson }\end{array}$} \\
\hline & & & & & $\begin{array}{c}\text { R } \\
\text { Square } \\
\text { Change }\end{array}$ & $\begin{array}{c}\text { F } \\
\text { Change }\end{array}$ & df1 & df2 & $\begin{array}{l}\text { Sig. F } \\
\text { Change }\end{array}$ & \\
\hline 1 & $.944^{\mathrm{a}}$ & .890 & .878 & 2915.0155 & .890 & 73.153 & 1 & 9 & .000 & \\
\hline 2 & $.972^{b}$ & .945 & .932 & 2182.6237 & .055 & 8.053 & 1 & 8 & .022 & 2.543 \\
\hline
\end{tabular}

a. Predictors: (Constant), Real Estate, Renting and Business Activities

b. Predictors: (Constant), Real estate, Renting and Business Activities, Other services

c. Dependent Variable: GDP

The value that is interpreted is $\mathrm{R}$ Square which shows that the change in economic growth depends $94.5 \%$ on the change in the independent variables. Thus, FDI by economic activity (real estate, rent and business activities, education, health and social work, social and personal services) affect $94.5 \%$ of economic growth.

The ANOVA table is used to test the relevance of the model as a whole. Here, the table gives the level of reliability for the regression model. Value Sig. is 0.000 and this indicates that the regression model is significant as a whole.

Table 9: ANOVA Table for the Regression Model 2a

\begin{tabular}{|c|c|c|c|c|c|c|}
\hline \multicolumn{2}{|c|}{ Model } & Sum of Squares & df & Mean Square & $\mathbf{F}$ & Sig. \\
\hline \multirow[t]{3}{*}{1} & Regression & 621608038.038 & 1 & 621608038.038 & 73.153 & $.000^{\mathrm{b}}$ \\
\hline & Residual & 76475836.689 & 9 & 8497315.188 & & \\
\hline & Total & 698083874.727 & 10 & & & \\
\hline \multirow[t]{3}{*}{2} & Regression & 659973103.271 & 2 & 329986551.636 & 69.269 & $.000^{c}$ \\
\hline & Residual & 38110771.456 & 8 & 4763846.432 & & \\
\hline & Total & 698083874.727 & 10 & & & \\
\hline \multicolumn{7}{|c|}{ a. Dependent Variable: GDP } \\
\hline \multicolumn{7}{|c|}{ b. Predictors: (Constant), Real Estate, Renting and Business Activities } \\
\hline \multicolumn{7}{|c|}{ c. Predictors: (Constant), Real estate, Renting and Business Activities, Other services } \\
\hline
\end{tabular}

Table 10 presents the regression coefficients. To summarize, the model forecast result is as follows:

$\mathrm{GDP}=33265.003+13.175 \mathrm{X} 1+61.244 \mathrm{X} 2$

As can be seen, the constant value is 33265.003. Its meaning is that even if FDI in economic activities (real estate, renting and business activities, education, health and social work, social and personal services) will be zero, GDP will be 33265.003 . 
With the increase of one unit in FDI in real estate, renting and business activities, the GDP will increase 13,175 units and the increase of one unit of FDI in education, health and social work, social and personal services will increase the GDP -in for 61,244 units.

As a result we conclude that there is a significant impact of FDI on economic growth by sectors of economic activity and $\mathbf{H} 2$ hypothesis is successfully accepted.

\begin{tabular}{|c|c|c|c|c|c|c|}
\hline \multirow{2}{*}{\multicolumn{2}{|c|}{ Model }} & \multicolumn{2}{|c|}{$\begin{array}{l}\text { Unstandardized } \\
\text { Coefficients }\end{array}$} & \multirow{3}{*}{$\begin{array}{c}\text { Standardized } \\
\text { Coefficients } \\
\text { Beta }\end{array}$} & \multirow{3}{*}{$\begin{array}{c}\mathbf{t} \\
18.207\end{array}$} & \multirow{3}{*}{$\begin{array}{l}\text { Sig. } \\
.000\end{array}$} \\
\hline & & \multirow{2}{*}{$\begin{array}{c}\text { B } \\
35539.242\end{array}$} & \multirow{2}{*}{$\begin{array}{c}\text { Std. Error } \\
1951.993\end{array}$} & & & \\
\hline 1 & (Constant) & & & & & \\
\hline & $\begin{array}{l}\text { Real Estate, } \\
\text { Renting and Business } \\
\text { Activities }\end{array}$ & 13.536 & 1.583 & .944 & 8.553 & .000 \\
\hline \multirow[t]{3}{*}{2} & (Constant) & 33265.003 & 1666.850 & & 19.957 & .000 \\
\hline & $\begin{array}{l}\text { Real Estate, } \\
\text { Renting and Business } \\
\text { Activities }\end{array}$ & 13.175 & 1.192 & .918 & 11.054 & .000 \\
\hline & Other services & 61.244 & 21.581 & .236 & 2.838 & .022 \\
\hline
\end{tabular}

a. Dependent Variable: GDP

\section{Conclusion}

This study examined the impact of FDI on Kosovo's economic growth, for the period 2007-2017. From the literature review it was shown that foreign investments are expected to have a significant impact on the economic growth and development of host countries. In general, in theory, FDI is expected to boost economic growth in host countries by creating employment opportunities, increasing domestic investment, and facilitating technology transfer. Hypothesis testing results showed that there is a significant impact of FDI on economic growth. The value found which was interpreted was R Square which showed that the change in economic growth depends on $36.5 \%$ of the change in the independent variables. So, foreign direct investment affects $36.5 \%$ of economic growth. To see if this impact is significant, the Anova table was used. Value Sig. is .049 and showed that the model is significant at its level.

Also from the second hypothesis, the value found which was interpreted was $R$ Square which showed that the change in economic growth depends $94.5 \%$ on the change in the independent variables. Thus, FDI by economic activity (real estate, rent and business activities, education, health and social work, social and personal services) affect $94.5 \%$ of economic growth. The Anova table was used to test the relevance of the model as a whole. Value Sig. is 0.000 and this indicates that the regression model was completely significant. These findings are consistent and compatible with some previous studies, such Pegkas (2015), which demonstrated that FDI has a positive and significant impact on economic growth as economic theory predicts. So, FDI plays a significant role on economic growth in Eurozone. 
Since, Kosovo is characterized by low production, high unemployment, favorable climate and high quality agricultural land. For this reason, the agricultural sector should be stimulated through specific policies and concrete incentives to increase investor interest in it. In general, Kosovo institutions and all other relevant actors should be more engaged in creating better conditions for current investors, in order to attract potential foreign investment in Kosovo. Institutions in Kosovo should continue to improve and advance the legal framework for the legal security of investors, including the establishment of legal mechanisms to ensure the implementation of contracts and procedural instruments that guarantee faster procedures of possible cases / disputes. If Kosovo is able to reform its institutions and change the image of its government, foreign investment will begin to flow into the country and Kosovo's economy will begin to grow. This study provides important information for those who will be doing research on this topic in Kosovo. Future work and research may include other variables to measure the impact of FDI on economic growth. Even the most detailed effects of FDI can be explored through other factors, showing the relationships between them and making comparisons. Other regression models can also be derived based on the inclusion of a more detailed approach to impact indicators on gross domestic product.

\section{Conflict of Interest Statement}

The author declares no conflicts of interests.

\section{About the Author}

Isuf Qabrati is Assistant (engaging) at the Faculty of Economics, University of Prizren, Prizren. He has a master's degree in accounting and auditing. He is a member of the Society of Certified Accountants and Auditors of Kosovo, in the second level Certified Accountant. His research interests relate to financial economics, macroeconomics, microeconomics, accounting, etc.

\section{References}

Adefabi, R. A. (2011). Effects of FDI and human capital on economic growth in SubSaharan Africa. Pakistan journal of social sciences, 8(1), 32-38.

Alfaro, L., \& Matthew, J. (2012). Foreign Direct Investment and Growth. Boston: The Evidence and Impact of Financial Globalization, Harvard Business School.

Alvaro, L., Chanda, A., Kalemli-Ozcan, S., and Sayek, S. (2006). How Does Foreign Direct Investment Promote Economic Growth? Exploring the Effects of Financial Markets on Linkages, Working Paper 07-013.

Anwar, S., \& Nguyen, L. P. (2010). Foreign Direct Investment and Economic Growth in Vietnam. Asia Pacific Business Review, 16(1-2), 183-202.

Bartels, F. L., \& Crombrugghe, S. (2009). FDI Policy Instruments: Advantages and Disadvantages. Vienna: United Nations Industrial Development Organization. 
Bengoa, M., \& Sanchez-Robles, B. (2003). Foreign direct investment, economic freedom and growth: new evidence from Latin America. European journal of political economy, 19(3), 529-545.

Çakërri, L. (2019). Ndikimi i Investimeve të Huaja Direkte mbi Rritjen Ekonomike në Shqipëri: Roli i Kapacitetit Absorbues. Tiranë: Universiteti i Tiranës, Fakulteti i Ekonomisë.

Denisia, V. (2010). Foreign Direct Investment Theories: An Overview of the Main FDI Theories, European Journal of Interdisciplinary Studies, No. 3.

Dritsaki, C., \& Dritsaki, M. (2012). Exports and FDI: A Granger causality analysis in a heterogeneous panel. Economics Bulletin, 32(4), 3128-3139.

Dritsakis, N., \& Stamatiou, P. (2014). Exports, foreign direct investment, and economic growth for five European countries: Granger causality tests in panel data. Applied Economics Quarterly, 60(4), 253-272.

Falki, N. (2009). Impact of foreign direct investment on economic growth in Pakistan. International Review of Business Research Papers, 5(5), 110-120.

Javorick, B. S. (2004). Does Foreign Direct Investment Increase the Productivity of Domestic Firms? In Search of Spillovers Through Backward Linkages. American Economic Review, 94(3), 605-627.

Jyun-Yi, W., \& Chih-Chiang, H. (2008). Does foreign direct investment promote economic growth? Evidence from a threshold regression analysis. Economics Bulletin, 15(12), 1-10.

Kilic, C., Bayar, Y., \& Arica, F. (2014). Effects of currency unions on foreign direct investment inflows: the European economic and monetary union case. International Journal of Economics and Financial Issues, 4(1), 8.

Kukaj, H., \& Ahmeti, F. B. (2016). The importance of foreign direct investments on economic development in transitional countries: a case study of Kosovo. European Scientific Journal, 12(7).

Louzi, B. M., \& Abadi, A. (2011). The impact of foreign direct investment on economic growth in Jordan. IJRRAS-International Journal of Research and Reviews in Applied Sciences, 8(2), 253-258.

Maku, O. (2015). Macroeconomic Consequences of Foreign Direct Investment in Nigeria: An Empirical Analysis. European Journal of Business and Management, 7(22).

Mehic, E., Silajdzic, S., \& Babic-Hodovic, V. (2013). The impact of FDI on economic growth: Some evidence from Southeast Europe. Emerging Markets Finance and Trade, 49(sup1), 5-20.

Mottaleb, K. A. (2007). Determinants of foreign direct investment and its impact on economic growth in developing countries.

Omri, A. (2014). The nexus among foreign investment, domestic capital and economic growth: Empirical evidence from the MENA region. Research in economics, 68(3), 257-263.

Pegkas, P. (2015). The impact of FDI on economic growth in Eurozone countries. The Journal of Economic Asymmetries, 12(2), 124-132. 
Siddique, H. M. A., Ansar, R., Naeem, M. M., \& Yaqoob, S. (2017). Impact of FDI on economic growth: Evidence from Pakistan. Bulletin of Business and Economics, 6(3), $111-116$.

Creative Commons licensing terms

Authors will retain copyright to their published articles agreeing that a Creative Commons Attribution 4.0 International License (CC BY 4.0) terms will be applied to their work. Under the terms of this license, no permission is required from the author(s) or publisher for members of the community to copy, distribute, transmit or adapt the article content, providing a proper, prominent and unambiguous attribution to the authors in a manner that makes clear that the materials are being reused under permission of a Creative Commons License. Views, opinions and conclusions expressed in this research article are views, opinions and conclusions of the author(s). Open Access Publishing Group and European Journal of Economic and Financial Research shall not be responsible or answerable for any loss, damage or liability caused in relation to/arising out of conflict of interests, copyright violations and inappropriate or inaccurate use of any kind content related or integrated on the research work. All the published works are meeting the Open Access Publishing requirements and can be freely accessed, shared, modified, distributed and used in educational, commercial and non-commercial purposes under a Creative Commons Attribution 4.0 International License (CC BY 4.0). 